\title{
Scientific Periodicals as a Basic Requirement for Engineering and Agricultural Research
}

$\mathrm{T}$ HE SUBJECT of the interrelationships of subject matter in the various fields of learning is one which has interested librarians for many years. That these relationships exist and that their importance has increased in recent years is well known. Of particular interest has been the increasing interrelationship in and between the sciences and research being carried on in the applied fields of engineering and agriculture. It is the intent of this paper to study this latter relationship on the basis of the use of periodicals in research in a number of selected fields of engineering and agriculture. Particular emphasis has been given to the analysis of the subject fields in the pure sciences as they relate to the applied fields.

The method selected for this study is that of reference counting. This method, since first reported by Gross and Gross, ${ }^{1}$ has been used by librarians as a tool in aiding in the selection of periodicals. While objections which have been raised to the indiscriminate use of the method for the selection of periodicals may have some validity, its usefulness for the purposes proposed here should be apparent. The periodicals chosen for this study are ones in which is reported much of the research being carried on in the subject fields under consideration. Therefore, the references cited in these

\footnotetext{
${ }^{1}$ Gross, P. L. K., and Gross, E. M. "College Libraries and Chemical Education." Science 66:385-89, Oct. 28,1927 .
}

papers should represent the references of greatest importance in carrying out the research projects reported.

The subjects chosen for this study are those of soils and dairying in the agricultural field, and mechanical and metallurgical engineering in the technical field.

In making the reference counts, it was necessary to employ some arbitrary rules. The references recorded were limited to periodicals or serials as defined by inclusions in the Union List of Serials. Thus most government documents were eliminated as well as reports of congresses and all material from books of a nonserial nature. References to abstracting journals were also omitted.

So that each subject field might be reported on the basis of its total usefulness to the applied field studied, the references used were not limited to the periodicals most often cited but included all periodicals cited. This seemed essential to a correct interpretation. Even though the individual titles cited only a few times would undoubtedly vary if different samples were taken, the total number of periodicals in the various subject fields would not vary as long as an adequate sample was used.

That the size of the samples used in this study was adequate was proved by the fact that half as large a sample gave almost exactly the same percentage of references in the various subject fields. 
The periodicals used in the fields covered and the periods covered were:

In Agriculture:

Soils-Soil Science, 1936-37, 1944-45

Dairying-Journal of Dairy Science, 1936-

37, 1944-45

\section{In Engineering:}

Mechanical engineering-Mechanical Engineering, 1938-39, 1944-45; Journal of Applied Mechanics, 1938-39, 1943-44; Transactions of the American Society of Mechanical Engineers, 1938-39, 1943-44

Metallurgical engineering-Transactions of the American Society for Metals, 193637, 1944-45; Transactions of the American Institute of Mining and Metallurgical Engineers, "Institute of Metals" and "Iron and Steel" sections, 1937, 1945

The double period was used in each case to counteract any temporary trend within individual fields of research such as might be apparent during the period in which research was directed in a large measure toward wartime projects.

The references were tabulated on separate sheets for each periodical cited and were recorded in three period groups: before 1910 , 1911 to 1929 , and since 1930 . The tabulations for the periods used are not reproduced here. Sample calculations showed that early references had larger percentages in the fields of the pure sciences than did later references, which was to be expected.

Periodicals cited were verified as thoroughly as possible so that the same title would not be counted repeatedly under different entries in the totals of periodicals cited. Each title was then classified by the Library of Congress classification into its larger subject field on the basis of Library of Congress cards when possible, or by the classification itself. While the classification used for some individual titles might be questioned, the majority of titles fell defi- nitely into individual fields. The resulting totals would be affected very little by changing the few titles not clearly classifiable.

Tables I and II include the total number and percentages of titles cited as well as the totals and percentages of references in each subject field. The percentage figure for the total number of references in each field carries the most significance since, assuming an adequate sample, it remains constant regardless of the size of the sample. The percentage of periodicals cited would vary according to the size of the sample since it depends on the number of periodicals published in the various fields. As the number of periodicals cited in one field approaches the total number published in that field, the corresponding percentage of all of the periodicals cited decreases, since the number of periodicals cited in remotely related fields will continue to increase with an increasing sample.

An analysis of Table I reveals that in both the fields of soil and dairying research, periodicals in the fields of the pure sciences supply approximately one-third of the references. In soils research, general scientific periodicals and those in chemistry and botany are of nearly equal importance, followed by those covering physiology and bacteriology. In dairying, over half of the references to pure science periodicals are to those in physiology, which here includes biological chemistry. Chemical and general scientific periodicals are also important. The large number of references in the physiology section are concentrated in a relatively small number of periodicals.

In the field of dairy science, approximately 60 per cent of the references are from journals in the field of agriculture while in soils the percentage is approximately 50. Engineering, chiefly chemical, accounts for approximately 7 per cent in each field. In dairy research, periodicals in applied medi- 
TABLE I

References and Periodicals Cited in Two Fields of Agriculture

\begin{tabular}{|c|c|c|c|c|c|c|c|c|}
\hline & \multicolumn{4}{|c|}{ Soils } & \multicolumn{4}{|c|}{ Dairying } \\
\hline & 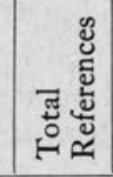 & 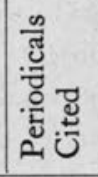 & 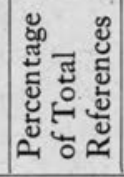 & 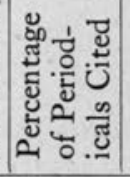 & 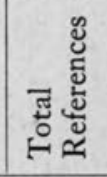 & 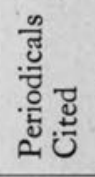 & 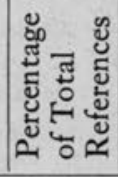 & 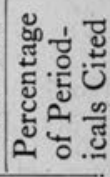 \\
\hline Science-General. & 254 & 64 & 6.9 & $15 \cdot 3$ & 134 & 34 & 3.8 & 8.4 \\
\hline Mathematics and Physics. . & 26 & 10 & 0.7 & 2.4 & 7 & 6 & 0.2 & 1. 5 \\
\hline Chemistry............. & 222 & 40 & 6.0 & $9 \cdot 5$ & 312 & 39 & 8.8 & 9.6 \\
\hline Geology .............. & 37 & 14 & I. 0 & $3 \cdot 3$ & 2 & 2 & 0.1 & 0.5 \\
\hline Biology-General......... & 75 & 19 & 2.0 & $4 \cdot 5$ & 35 & 14 & I. 0 & $3 \cdot 5$ \\
\hline Botany...$\ldots \ldots \ldots \ldots$ & 290 & 32 & 7.9 & 7.6 & 12 & 8 & 0.3 & 2.0 \\
\hline Physiology and Zoology.... & 134 & 19 & $3 \cdot 7$ & $4 \cdot 6$ & 726 & 33 & $20 \cdot 3$ & 8.1 \\
\hline Bacteriology ........... & 99 & 6 & 2.7 & I $\cdot 4$ & 39 & 5 & I. I & 1.2 \\
\hline Total Science........... & II 37 & 204 & 30.8 & $4^{8} .6$ & 1267 & I4 I & $35 \cdot 5$ & 34.8 \\
\hline $\begin{array}{l}\text { Agriculture-General ....... } \\
\text { Plant Culture, Horticulture, }\end{array}$ & $175^{8}$ & 93 & 47.6 & 22.1 & 371 & 63 & 10.4 & $15 \cdot 5$ \\
\hline and Forestry $\ldots \ldots \ldots \ldots$ & 497 & 53 & I $3 \cdot 5$ & 12.6 & 32 & 7 & 0.9 & I. 7 \\
\hline Animal Industries . . . . . . . & 6 & 4 & 0.2 & I. 0 & 1392 & 77 & $39 \cdot 1$ & 19.0 \\
\hline Total Agriculture........ & $226 \mathrm{I}$ & 150 & $6 \mathrm{I} \cdot 2$ & $35 \cdot 7$ & 1795 & 147 & 50.4 & $36 \cdot 3$ \\
\hline $\begin{array}{l}\text { Chemical, Metallurgical, and } \\
\text { Mining Engineering... }\end{array}$ & & & & & & & & \\
\hline $\begin{array}{l}\text { Minıng Engineerıng....... } \\
\text { Miscellaneous Engineering }\end{array}$ & I95 & 18 & $5 \cdot 3$ & $4 \cdot 3$ & 205 & 29 & 5.7 & 7.1 \\
\hline and Technology......... & I8 & 10 & 0.5 & 2.4 & 66 & 15 & I. 9 & $3 \cdot 7$ \\
\hline $\begin{array}{l}\text { Total Engineering and } \\
\text { Technology } \ldots \ldots \ldots \ldots\end{array}$ & 213 & 28 & 5.8 & 6.7 & 271 & 44 & $7 \cdot 6$ & 10.9 \\
\hline Medicine............. & 70 & 29 & 1.9 & 6.9 & 225 & 68 & 6.3 & I6.8 \\
\hline Miscellaneous........... & II & 9 & 0.3 & 2.I & 6 & 5 & 0.2 & I. 2 \\
\hline Total. . & $369^{2}$ & 420 & & & 3564 & 405 & & \\
\hline
\end{tabular}

cine include 6 per cent of the references while in soil science the percentage is only 2 .

\section{Discrepancy in Two Fields}

Table II indicates a greater discrepancy in the two fields chosen as to subject importance. In engineering it would be expected that those applied fields closely related to a similar pure science, such as chemical engineering is to chemistry, would have a greater need for the publications in the pure sciences than would an applied science farther removed, such as civil engineering. The two fields chosen occupy positions between the two mentioned above. Metallurgical engineering research makes a good deal of use of the publications in the pure sciences as shown by the 23 per cent recorded. In mechanical engineering the percentage is less than half of this amount. The metallurgical engineering references in science are chiefly in general science periodicals, physics, and chemistry. The same fields are important in mechanical engineer- 
TABLE II

References and Periodicals Cited in Two Fields of Engineering

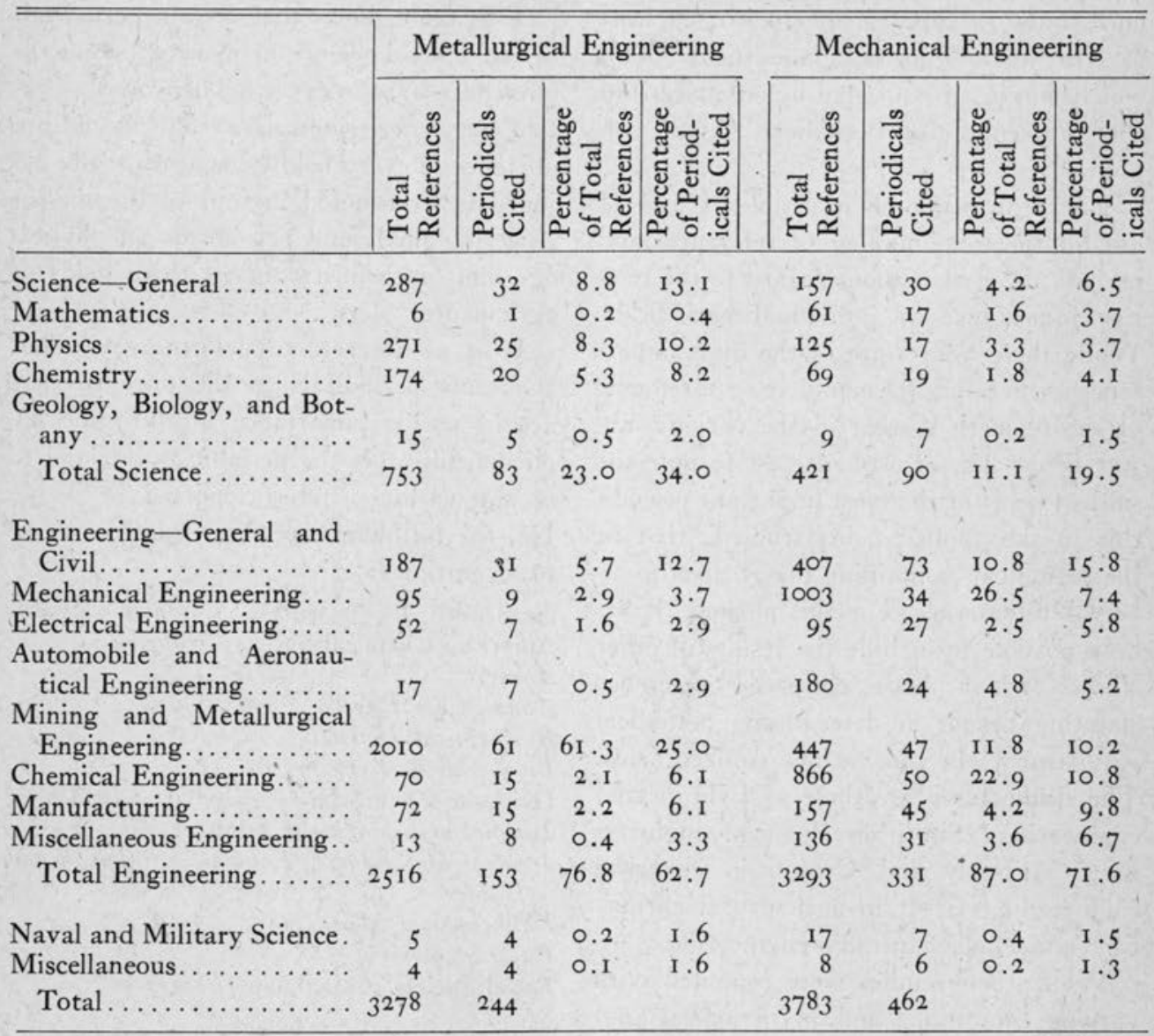

ing with mathematics increasing in importance. Three-fourths of the references cited in metallurgical journals were in periodicals in the technical and engineering fields with $6 \mathrm{I}$ per cent in mining and metallurgy. In mechanical engineering, 87 per cent of the references were distributed in the various engineering fields.

In these tables, the references to the magazines checked have been included in the reference counts. Since these periodicals and others high on the list will be easily available to the research worker, the obligation for the library's furnishing the impor- tant related materials becomes even greater. Elimination of these obviously required journals from the percentage counts tends to emphasize even more strongly the periodicals in the related fields, particularly the pure sciences. If, for example, the relative importance for soils research of journals other than Soil Science, the Journal of the American Society of Agronomy, and the Proceedings of the Soil Science Society of America is considered, the percentage of remaining references in the pure sciences is raised from 31 to 49 and the percentage in agriculture decreased from $6 \mathrm{I}$ to 39 . As 
far as the library is concerned, therefore, the important periodicals in the pure sciences must be supplied in quantity at least as great as those in the applied field. This conclusion is substantiated by an analysis of the "Percentage of Periodicals Cited" column.

The figures quoted in Tables I and II are for the total number of references and periodicals cited without regard to the relative importance of individual periodicals. While these figures are of the most importance in revealing the complete requirements of the research worker in the various subject fields, it is also of interest to note the subject fields of the most important periodicals in the applied fields studied; that is, the periodicals containing the greatest number of references. For this purpose, it has been possible to include the results of other studies which have employed reference counting to aid in determining periodical requirements in the various subject fields. The studies used are those of Lyle in civil engineering, ${ }^{2}$ Smith in chemical engineering, ${ }^{3} \mathrm{McNeely}$ and Crosno in electrical engineering, ${ }^{4}$ Croft in agricultural chemistry, ${ }^{5}$ and Hooker in radio engineering. ${ }^{5}$

While these studies were compiled with varying limitations and in periodicals not always of a research nature, the results, as far as they indicate the most important periodicals in each subject field, can be accepted as comparable to similar results in this study. The subject distributions of the most often quoted journals in the five references mentioned and in the four fields

2 Lyle, Guy R. "The Selection of Civil Engineering Journals in the College Engineering Library." Master's thesis. Columbia University, r932.

Smith, Maurice H. "The Selection of Chemical Smith, Maurice $H$. "The Selection of Chemical
Engineering Periodicals in College Libraries." College and Research Libraries 5:217-27, June r944,

McNeely, J. K., and Crosno, C. D. "Periodicals for Electrical Ėngineers." Science 72:81-84, July 25,

${ }^{1930}$ C roft, K. "Periodical Publications and Agricultural Analysis; A Bibliographical Study." Journal of Chemical Education 18:315-16, July r941.

'Hooker, R. H. "A Study of Scientific Periodicals." Review of Scientific Instruments $6: 333-38$, November 1935 . covered by this study are indicated in Table III.

This table shows that certain periodicals in the general science field were among the most important in every field covered. Certain chemical periodicals were of special importance in every field except two. Physics journals were noted in four of the six engineering fields and periodicals on physiology and biochemistry in all three fields of agriculture.

It is of interest to determine whether the same periodicals in the pure sciences are of major importance in the same applied fields. Of the periodicals referred to in the various studies reported in Table III, the following are recorded from three to seven times:

Académie des Sciences. Comptes Rendus American Chemical Society. Journal

Analyst

Annalen der Physik

Biochemical Journal

Biochemische Zeitschrift

Deutsche Chemische Gesellschaft. Berichte Journal of Biological Chemistry

Journal of Research, London, Edinburgh and Dublin

Philosophical Magazine

Physical Review

Royal Society of London. Proceedings

Science

Zeitschrift für Physik.

The Journal of the American Chemical Society appeared in seven of the nine lists, and the Proceedings of the Royal Society and the Comptes Rendus of the Paris Academy in six. In addition, ten titles are recorded among the most important in each of two of the studies listed in the table.

Dalziel also has studied periodicals in the field of electrical engineering. ${ }^{7}$ In his study reference counts were made in twenty journals chosen as the most used in this field. In this case the importance of periodicals

\footnotetext{
"Dalziel, Charles F. "Evaluation of Periodicals for Electrical Engineers." Library Quarterly 7:354-72, July 1937.
} 
TABLE III

Subject Distribution of Most Frequently Quoted Periodicals in Various Fields of Agriculture and Engineering

\begin{tabular}{|c|c|c|c|c|c|c|c|c|c|}
\hline & 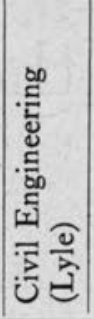 & 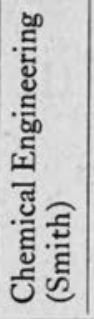 & 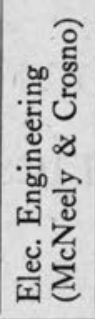 & 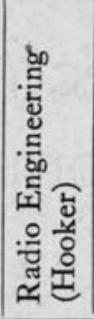 & 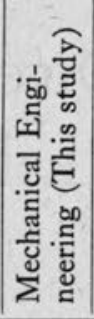 & 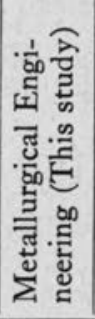 & 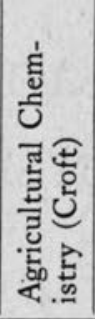 & 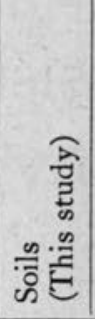 & 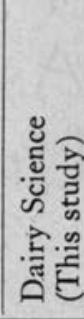 \\
\hline Science-General. & 2 & 3 & 3 & 6 & 2 & 5 & 2 & 2 & 2 \\
\hline Physics.............. & - & - & 4 & 7 & I & 4 & 一 & - & - \\
\hline Chemistry ............ & - & 8 & 2 & - & I & 3 & 10 & 3 & 3 \\
\hline 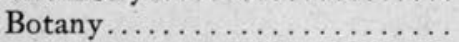 & - & - & - & - & - & - & 一 & 3 & - \\
\hline Physiology and Biochemistry... & - & 2 & - & - & - & 一 & 4 & 3 & - \\
\hline Bacteriology ............... & - & - & - & - & - & - & - & 2 & 1 \\
\hline Total Science. . & 2 & I3 & 9 & 13 & 4 & 12 & 16 & I3 & 14 \\
\hline $\begin{array}{l}\text { Engineering-General........... } \\
\text { Civil Engineering and Engineer- }\end{array}$ & 5 & 2 & I & - & 3 & - & - & - & - \\
\hline ing Materials..................... & 8 & - & - & - & I & I & 一 & 一 & 一 \\
\hline $\begin{array}{c}\text { Sanitary and Municipal Engi- } \\
\text { neering } \ldots \ldots \ldots \ldots \ldots \ldots \ldots\end{array}$ & 2 & - & - & - & - & - & - & - & - \\
\hline Roads and Pavements . . . . . . . & I & - & - & - & $\therefore$ & - & - & - & 一 \\
\hline Railroad Engineering. .. & - & - & I & - & I & - & - & - & - \\
\hline Mechanical Engineering......... & - & 2 & - & - & 3 & 1 & - & - & - \\
\hline Electrical Engineering.......... & 一 & - & 12 & 17 & - & - & - & - & - \\
\hline $\begin{array}{c}\text { Automobile and Aeronautical } \\
\text { Engineering...... }\end{array}$ & I & - & - & - & I & - & - & 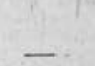 & \\
\hline Mining and Metallurgical Engi- & & & & & & & & - & \\
\hline I Engineering... & ${ }^{1}$ & $\begin{aligned} 3 \\
\text { II }\end{aligned}$ & 一 & - & $\begin{array}{l}7 \\
4\end{array}$ & I6 & 5 & 2 & 2 \\
\hline Pho & - & - & - & 2 & - & - & - & - & - \\
\hline Manufacturing ............... & - & 一 & - & - & 2 & I & 2 & - & 一 \\
\hline $\begin{array}{l}\text { Total Technology and Engi- } \\
\text { neering................. }\end{array}$ & 18 & 18 & 14 & 19 & 22 & 19 & 7 & 2 & 2 \\
\hline & I & I & 一 & - & 一 & 一 & 5 & io & ${ }^{1} 4$ \\
\hline & - & 一 & - & - & 一 & - & 6 & - & I \\
\hline Military Science..... & I & - & - & - & - & - & - & 一 & \\
\hline
\end{tabular}

in the pure sciences for electrical engineering was accepted before the counts were made, for of the twenty journals checked, seven were from the pure sciences. All references cited in the scientific periodical articles were counted, resulting in the inclusion of much material not closely related to electrical engineering and an overbalancing toward scientific periodicals, particularly physics.

That periodical indexes do not cover all of the periodicals most useful to a research worker in the applied fields is indicated by (Continued on page 375) 
The Library has been an active participant in interlibrary affairs in Georgia, particularly in the development of the regional Union Catalog and the cooperative library program of the University Center of Atlanta. The Director of Libraries has been a member of the Library Committee of the University System of Georgia which during the war, however, has practically ceased to function.

The Director of Libraries is a member of the Executive Committee of the Graduate Faculty. The inclusion of the Director in this Committee may or may not be the result of the library survey.

The great upheaval of the war and the present readjustments which are following the return to peace make it hard to evaluate any changes in the use of the Library. We have observed a considerable increase in library use by the student body and a certain increase by the Faculty. The total use of the Library, however, is not yet satisfactory. There is a far better attitude on the part of the library public toward the Library and the library program than existed in 1940; and as soon as it is possible for the University Faculty and student body to stabilize, the library use will doubtless improve.

We are in the process of preparing plans for a new library building which is to be constructed as soon as conditions permit. There have been no improvements in existing facilities and will probably be none, in view of the

\section{Scientific Periodicals}

\section{(Continued from page 359)}

a study of the Agricultural Index made by Orr. ${ }^{8}$ Of the forty-seven most quoted periodicals, only five were from the pure science field, a percentage far below that shown above. A similar study by Pohle ${ }^{9}$ of material included in the Experiment Station Record shows a similar trend. That abstracting and indexing services should remain close to their indicated fields seems entirely justifiable, however, for the large

8 Orr, Robert W. "Preliminary Survey of the Agricultural Index as a Bibliographic Service for Land-grant College and University Libraries." Master's thesis. Columbia University, r939.

Pohle, G. A. "Study of the Agricultural Index and Experiment Station Record, June 1936 to July 1937." Thesis. University of Michigan, I940. prospects for the new library building. This building is not the result of the library survey.

Training in Library Science has not been developed, largely because of the disruption from the war. It is part of the Library's plans to establish an adequate program for the training of school librarians and teacherlibrarians and for training persons for junior positions in the public libraries in the State.

The results of all the five surveys have not been so extensive or so substantial as those set forth by Dr. Parker. But they are substantial. The criticism could also be made that the surveys are very much alike in form and scope, that they are elementary, that when one is read there is little need to read the others. Such criticism is easy to make but is wide of the mark. They have been somewhat alike because they represent prescriptions for libraries, for different libraries, however, and they are directed at specific as well as general ends. They are elementary because they have been intended for administrative officers and faculty members who are not experts in library administration but whose sympathetic understanding and cooperation are essential to the carrying out of an effective, significant library program.

amount of duplication already existing would be greatly increased should they attempt to cover all important related fields.

This study leads to the conclusion that librarians as well as makers of the professional college curriculum are entirely justified in stressing the importance of the pure sciences. It is clearly shown that the importance of periodicals in the individual sciences and of such general publications as scientific society proceedings cannot be judged on the basis of their value to one or two subjects but must be selected on the basis of their value to all of the related fields of research, both pure and applied. 